\title{
Pergulatan Ideologi dalam Penciptaan Musik Kontemporer Bali
}

\author{
I Gede Arya Sugiartha \\ Institut Seni Indonesia Denpasar \\ Jl. Nusa Indah Denpasar Bali, 80235
}

\begin{abstract}
This composition studies the esthetic dynamic of the occurances of new creation of Bali musics with new musical concept within the last 3 decades. Creativity with deconstruction approach has received various responds from the society. Qualitative method using critical paradigm as thinking foundation and postmodernism is a key theory in this paradigm reasearch. The form of the research is conducted by developing interpretation of the meaning through esthetics theoretical approach (ideology, ethnomusicology, and semiotics) and Jacques Derrida's deconstruction. The result of this research shows that creativity of new creation of Bali Musics was motivated by internal factors as the artist ideology and new enthusiasm in interpreting preservation concepts of music tradition; and external factors that is Bali musics in global konstelation. The form of this music creativity can be classified into new creation music creativity and experimental music creativity. New creation of Bali music creativity affects on the artist, Bali music existence, and the society behavior; also possessing meaning of culture changes, esthetics wealth, and the construction of new awareness.
\end{abstract}

Keywords: Ideology conflict, music creation, and contemporary

\begin{abstract}
ABSTRAK
Tulisan ini menelaah dinamika estetik munculnya musik-musik Bali garapan baru dengan konsep-konsep musikal yang berbeda selama kurun waktu tiga dekade terakhir ini. Kreativitas dengan pendekatan dekonstruksi ini mendapat respon yang beragam dari masyarakat setempat. Metode kualitatif dengan menggunakan paradigma kritis sebagai landasan berpikir dan postmodernisme sebagai teori kunci dalam paradigma kajian ini. Bentuk kajian dilakukan dengan mengembangkan penafsiran makna melalui pendekatanteori estetika (ideologi, etnomusikologi, dan semiotika) dan dekonstruksi Jacques Derrida. Temuan hasil penelitian ini yakni bahwa kreativitas musik Bali garapan baru didorong oleh faktor internal yang meliputi ideologi seniman dan semangat baru dalam memaknai konsep-konsep pelestarian musik tradisi; dan faktor eksternal, yaitu musik Bali dalam konstelasi global. Wujud kreativitas musik ini dapat diklasifikasikan menjadi kreativitas musik kreasi baru dan kreativitas musik eksperimental. Kreativitas musik Bali garapan baru berdampak terhadap seniman pencipta, eksistensi musik Bali, dan sikap masyarakat; serta mengandung makna perubahan budaya, kekayaan estetik, dan terbangunnya kesadaran baru.
\end{abstract}

Kata kunci: Pergulatan ideologi, penciptaan musik, dan kontemporer 


\section{PENDAHULUAN}

Karya seni yang terlahir melalui proses cipta, rasa, dan karsa oleh sang seniman adalah hasil rekayasa kultural yang memiliki "daya hidup". Dengan daya hidup, kekuatan karya seni menjadi sangat luas karena ia tidak hanya berfungsi untuk pemenuhan kepuasan estetik, melainkan dapat menciptakan pengaruh pada ranah kehidupan yang lebih besar. Dari lintasan sejarah telah terbukti bahwa karya seni sering dijadikan sarana atau "kendaraan tumpangan" untuk tujuan-tujuan tertentu, seperti propaganda politik, ekonomi, sosial, selain untuk kepentingan seni itu sendiri. Seni akhirnya menjadi medan pertempuran makna antara fakta dan fiksi, tradisi dan modern, fungsional dan presentasi estetis, ritual dan tontonan, sakral dan profan, serta seni murni dan terapan. Hal ini tentu disebabkan oleh begitu luasnya daerah jelajah seni dalam upaya menemukan medan makna yang tak terbatas.

Pergulatan wacana dan ideologi tidak dapat dihindari terutama sejak tiga dekade terakhir ini dengan berkembangnya bentuk-bentuk seni baru yang juga ingin mendapat hak hidup dan pengakuan. Salah satu adalah pergulatan ideologi tentang lahirnya musik kontemporer yang kini sedang tumbuh, berkembang untuk bisa eksis di Bali.

Pada mulanya persoalan musik kontemporer adalah masalah konsep penciptaan musik yang memiliki kalangan terbatas, yaitu para mahasiswa dan akademisi lembaga-lembaga pendidikan seni. Beberapa calon dan komponis muda berbakat khususnya mereka yang sempat berinteraksi dengan komponis luar daerah dan luar negeri menemukan cara pandang baru dalam memaknai penciptaan musik Bali. Secara tradisional, para komponis Bali dalam menciptakan karya musik diikat oleh berbagai aturan seperti struktur, fungsi, tata penyajian termasuk cara garap, yang oleh beberapa komponis muda dianggap membatasi kreativitas. Muncul upaya-upaya pembaharuan dengan berbagai cara mulai dari memberi variasi hingga ingin melepaskan diri dari aturan-aturan tradisi.

Cara pandang baru yang telah tumbuh di Bali pada awal dekade 1970-an dengan lahirnya musik dari batu karya Wayan Dibia, kemudian mendapat angin segar ketika diadakannya Pekan Komponis Muda (PKM) I di Jakarta pada tanggal 19-22 Desember 1979. Sesuai dengan visinya, PKM ingin mengajak para seniman dari berbagai daerah di Indonesia untuk menyalurkan bakat kreatifnya lewat sebuah dialog budaya musik. Para komponis muda wakil dari berbagai daerah, seperti Jakarta, Sumatra Barat, Jawa Barat, Jawa Tengah, Daerah Istimewa Yogyakarta, Jawa Timur, dan Bali diajak berkreativitas melalui kekuatan budaya tradisi masing-masing kemudian berkumpul di Jakarta untuk mementaskan dan berdialog tentang karyakarya mereka (Harjana, 2004:37-38). Pada masa selanjutnya forum PKM ini diadakan setiap tahun dan kemudian menjadi ikon pembaharuan musik tradisi. Komponiskomponis muda Bali selalu ikut tampil dengan menyajikan karya-karya terbaru yang saat itu dikenal dengan nama "komposisi baru" untuk berpatisipasi dalam forum tersebut. Dari sinilah wacana kreativitas penciptaan musik baru mulai mengemuka khususnya di kalangan masyarakat akademis.

Namun satu hal yang perlu dicermati, pada masa awal perkembangannya para komponis justru belum berani menggunakan istilah kontemporer pada karyakarya mereka. Pada umumnya mereka menggunakan istilah-istilah lain, seperti 
komposisi baru, kreasi baru, atau eksperimental. Hal ini cukup beralasan karena batasan tentang terminologi musik kontemporer khususnya di Bali lebih dipahami sebagai "ekstrem kiri", yaitu sesuatu yang dicipta dengan melakukan "pelanggaran" terhadap aturan-aturan yang berlaku pada musik tradisi. Hal inilah menimbulkan pergulatan ideologi, di satu pihak seniman muda ingin berkembang untuk lebih "membesarkan" khasanah musik, namun di pihak lain terutama masyarakat tradisi masih memerlukan proses pemahaman untuk dapat mengapresiasi kehadiran musik kontemporer Bali.

Tidak hanya terjadi pada masyarakat umum, di kalangan masyarakat akademik STSI/ISI Denpasar dimana penciptaan seni dijadikan pusat unggulan, kehadiran musik kontemporer juga mengalami pergulatan wacana dan ideologi. Muncul pertanyaan sederhana, mengapa kita perlu membuat musik yang aneh-aneh, susah dipahami, dan tidak menyenangkan, padahal kita telah memiliki musik tradisi yang adiluhung. Mengomentari pertanyaan sederhana ini muncul dua anggapan dikotomis. Pertama, seseorang menekuni musik kontemporer adalah karena memiliki ideologi baru dan daya kreatif sehingga karya-karyanya dianggap telah mampu menembus dan melampaui batasanbatasan seni konvensional. Mereka ini adalah para seniman yang selalu memperjuangkan kesetaraan hidup bagi musikmusik baru agar dapat bersanding dengan kebesaran musik tradisi. Oleh sebab itu mereka selalui mencari alternatif-alternatif baru, memberi pemahaman-pemahaman baru bagi pengembangan dunia kreativitas musik. Kedua, anggapan sebaliknya yang berupa sindiran, yaitu para penggiat musik kontemporer adalah para seniman yang tidak menguasai musik tradisi yang terkenal rumit, penuh konvensi, sehingga mereka beralih ke musik-musik aneh agar bisa membungkus kelemahannya dengan isu-isu kebebasan dan keleluasaan dalam berekspresi. Pergulatan wacana dan ideologi ini kendatipun terkesan sederhana dan cenderung hanya dianggap sebagai "bahan obrolan di warung kopi", namun memberikan signal yang dapat membuka jalan bagi sebuah studi lebih lanjut tentang musik kontemporer Bali.

Jika kita menengok kejadian masa lampau, pergulatan wacana dan ideologi dalam memaknai kehadiran bentuk-bentuk kesenian Bali sering terjadi. Umar Kayam (1981:38) menyatakan bahwa pada awal dekade tahun 1970-an terjadi penolakan masyarakat terhadap seni Kecak karya Sardono W Kusumo di Desa Teges, Gianyar. Penolakan disebabkan karena Sardono mencoba menafsirkan Kecak yang tradisional tersebut dengan eksperimen baru yang mungkin kala itu cukup aneh dan dikhawatirkan merusak tatanan yang telah ada. Selama sepuluh tahun Kecak gaya Sardono ini beradaptasi hingga akhirnya diterima oleh masyarakat Bali. Hal lainnya adalah polemik di media masa tentang pementasan seni-seni kontemporer yang dianggap mencoreng citra Pesta Kesenian Bali (PKB) tahun 1995. Seni pertunjukan kontemporer dianggap telah ke luar dari konsep-konsep estetika Bali, sehingga tidak sesuai dengan tujuan PKB yang ingin menggali, melestarikan, dan mengembangkan kesenian Bali (Bali Post, 17 Juni-1Juli 1995). Fenomena yang paling aktual dewasa ini adalah lahirnya tabuhtabuh kreasi baru Gong Kebyar yang dianggap "ngontemporer". Tabuh kreasi baru Gong Kebyar dewasa ini cenderung rumit dan susah dipahami, sampai-sampai para produser tidak mau merekam karena susah terjual. 
Mencermati fenomena ini cukup membuat kita merasa terpanggil untuk menelusuri kemudian menjelaskan kepada masyarakat. Adalah tugas para akademisi seni untuk selalu mencermati fenomena yang terjadi kemudian memberi pencerahan agar seni dapat tampil sesuai dengan fitrahnya, yaitu ekspresi artistik yang mengabdi untuk kesempurnaan dunia. Apa yang melatarbelakangi para seniman muda kita khususnya penggiat musik kontemporer Bali selalu berjuang menuntut "hak hidup" dan berdampingan dengan keperkasaan musik tradisi, perlu segera dicari jawabannya. Di sisi lain, kenapa sebagian masyarakat Bali menolak kehadiran kontemporer, juga perlu dicari jawabannya. Padahal, dari hasil penelitian para peneliti asing seperti Covarubias (1972), Claire Holt (1967) menyebutkan bahwa masyarakat Bali selalu terbuka dengan pengaruh asing, bahkan dalam bidang seni pengaruh asing dapat dijadikan bahan untuk diolah agar memperkaya khasanah seni yang telah dimiliki. Pergualatan wacana dan ideolog inilah yang akan dicermati lewat tulisan sederhana ini, tujuannya agar dapat menjembatani pemaknaan dikotomis untuk saling memahami dalam sebuah dialektika.

\section{METODE}

Penelitian ini merupakan penelitian kualitatif yang berada dalam wilayah ilmu Kajian Budaya dengan menggunakan paradigma kritis sebagai landasan berpikir dan postmodernisme sebagai teori kunci dalam paradigma, bentuk kajian dilakukan dengan mengembangkan paradoks-paradoks penafsiran makna dan membuka ruang kesadaran baru dalam memahami gejala kebudayaan kontemporer.

Berdasarkan objek kajiannya maka dalam penelitian ini dipinjam pandangan Geertz (dalam Sutrisno, 2005: 212) yang menegaskan bahwa budaya adalah suatu demensi yang aktif dan konstitutif dari kehidupan sosial. Selanjutnya, untuk membuka dan menangkap kompleksitas budaya maka ditempuh dengan metode hermeneutika deskripsi tebal (antropologi interpretatif). Sedangkan validasi data yang relevan untuk penelitian ini tidak hanya diperoleh dari wawancara dan sumber tercetak, tetapi juga melalui penelitian lapangan dan keterlibatan langsung dengan objek penelitian dengan menggunakan sumber data primer dan sumber data sekunder.

Teknik analisis datanya difokuskan pada penunjukan makna, deskripsi, dan penempatan data pada konteksnya dengan meminjam analisis model interaktif yaitu reduksi data, pemaparan data, dan simpulan melalui pelukisan serta verifikasi. Analisis data bersifat terbuka karena fenomena budaya yang diamati sedang dalam wacana ideologis atau praktis. Oleh karena itu, analisis data lebih ditujukan untuk mengungkap makna yang ada melalui refleksi informan terhadap sikap dan aktivitas mereka sehingga terjadi penafsiran intersubjektif.

\section{HASIL DAN PEMBAHASAN \\ Wacana Musik Kontemporer Bali}

Istilah musik kontemporer dewasa ini sudah sangat sering digunakan oleh para insan musik Indonesia termasuk di Bali. Namun harus diakui bahwa pengertian musik kontemporer yang tunggal dan bulat mungkin tidak akan pernah ada, karena itulah salah satu ciri khas musik kontemporer, yaitu bukan kebakuan format melainkan idealisme yang selalu berkembang. Secara etimologis kata kontemporer menunjuk pada arti "saat sekarang" atau sesuatu yang memiliki sifat kekinian. Kata tersebut tidak berarti sesuatu yang terputus dari tradisi, melainkan sesuatu yang dicipta sebagai hasil perkembangan tradisi sampai 
saat ini. Pada awal pembentukannya musik kontemporer bukanlah suatu gaya, melainkan sikap seniman yang setiap saat mencipta karya seni yang sarat dengan aktualitas kekinian dan selalu "kontemporer".

Gendon Humardani seperti yang dikutip Rustopo (1990:22-26) membatasi kontemporer sebagai suatu sikap berkesenian yang sejalan dengan konsep seni modern yang berorientasi pada masalahmasalah kehidupan masa kini. Sikap kontemporer terus menerus mengembangkan kreativitas, mewujudkan yang baru dan yang segar, mengakomodasi masalah kehidupan masa kini. Menurut Edi Sedyawati (1981:122), istilah kontemporer pengertiannya luas, rumusannya mudah dikatakan, tetapi tidak semudah menentukan batas-batasnya, bahkan cenderung kurang memberi manfaat. Sedyawati menawarkan suatu batasan yang bergeser dari arti katanya tetapi lebih mendekati maksud yang dituju, yaitu seni kontemporer adalah seni yang menunjukkan daya cipta yang hidup sesuai dengan kondisi kreatif dari masa terakhir.

Penerapan pengertian kontemporer dari yang semula sangat ideologis menjadi lebih khusus, yaitu mengarah ke sebuah gaya untuk menggolongkan karya-karya yang selalu disemangati pencarian kemungkinan baru, menekankan sifat anti kaidah-kaidah kompositoris, bahkan anti pada bentuk-bentuk penyajian musikal yang baku dan mapan (Mistortoify, 1991:3). Jadi musik kontemporer dimengerti sebagai musik "baru" yang dicipta dengan konsep, kaidah, dan suasana yang baru. Paham mengenai musik tidak lagi terbingkai pada sesuatu yang enak didengar saja, melainkan berkembang pada gagasan menampilkan proses eksplorasi bunyi sebagai yang utama dan medium ekspresi yang tak terbatas agar dapat mewadahi gagasannya. Dengan konsep ini akan memberikan kebebasan kepada penciptanya berinterpretasi berdasarkan pengalaman batinnya masing-masing. Namun harus juga diakui justru dengan bentuknya yang sangat bebas membuat penikmat sering kehilangan pegangan untuk bisa menikmati musik sekaligus memahami unsur-unsur kebebasan yang ditawarkan sang komponis.

Dalam rumusan lain, tokoh musik Indonesia Suka Harjana (2003:252-253) menyatakan.

“...Musik kontemporer tidak menunjuk kepada sesuatu apapun yang bersifat spesifik kecuali menyiratkan tentang suatu waktu "masa kini" atau sesuatu yang bersifat kekinian yang tidak dibatasi oleh suatu periode waktu tertentu. Sifat-sifat dasar musik kontemporer pada setiap zaman, dulu maupun kini tidak pernah berubah, yaitu menyangkut kebutuhan akan adanya pembaharuan sebagai tuntutan terhadap masa lalu yang dianggap sudah tidak relevan dan usang".

Musik kontemporer lahir sebagai dampak dari "transformasi sebuah zaman". Oleh sebab itu sosoknya bersifat sementara, entitasnya majemuk dan banyak varian. Sangat sulit untuk membuat batasan yang tunggal dalam segala aspeknya, karena terjadi kekaburan antara yang serius dengan yang hiburan, profesional dengan amatir, mutu dengan "setengah matang", adiluhung dengan recehan, asli dengan tiruan, bahkan sesungguhnya juga secara paradoks, antara masa lalu dengan masa kini, antara yang nyata dengan yang semu. Berbeda dengan musik masa lalu atau musik tradisi yang telah memiliki “wajah" baku, musik kontemporer sebagai aksi maupun reaksi tumbuh dalam suasana tanpa batas, tak ada satu pun tanda-tanda dan ciri-ciri yang mempersatukan wajahnya. 
Sifat-sifat musik kontemporer sesuai dengan seni-seni kontemporer pada umumya. Jiwa Atmaja (1993:31) menerangkan bahwa seni kontemporer adalah buah hasil kreativitas dan konstalasi kerja keras seniman yang ingin menuntut hak hidup yang sama dan berdampingan dengan seni-seni lainnya. Sementara di pihak yang lain idiom-idiom yang digunakan seniman kontemporer sering kali membawa jarak kerinduan dengan masyarakat; seringkali seni kontemporer menjangkau sesuatu yang jauh ke depan dan ke langit intelektualitas seperti misalnya menukik pada persoalan hidup, sementara masyarakat masih tetap mengupas kulit permukaan sebagai suatu gejala hidup, maka titik temu moralitas hanya akan merupakan impian masyarakat bersangkutan.

Di Bali, wacana tentang musik kontemporer yang diawali dengan lahirnya karya-karya dalam rangka Pekan Komponis Muda (PKM) di Jakarta merebak khususnya pada masyarakat akademik ASTI/STSI (kini ISI Denpasar) dan KOKAR Bali (kini SMK 3 Sukawati). Dalam rangka PKM beberapa karya yang lahir, yaitu Gema Eka Dasa Rudra, karya Nyoman Astita (1979), Trompong Beruk, karya Wayan Rai (1982), Sangkep, karya Nyoman Windha (1983), Kosong, karya Ketut Gede Asnawa (1984), Irama Hidup, karya Ketut Suryatini dan Wayan Suweca (1987), Bali Age dan Sumpah Palapa, karya Nyoman Windha (1988). Satu hal penting yang dapat dicermati dari konsep karya-karya musik PKM ini adalah terjadinya perubahan cara pandang, cita rasa dan kriteria estetik terhadap konsepsi seni yang terpola, standar, seragam, dan bersifat sentral menjadi lebih bebas dan personal. Hal ini menyebabkan pola garap menjadi beragam terjadinya vokabuler teknik garap dan aturan tradisi sehingga karya-karya terkesan aneh, nakal, bahkan mungkin urakan.

Pada tahun 1987 serangkaian dengan tugas kelas mata kuliah Komposisi karawitan VI, mahasiswa Jurusan Karawitan Semester VII ASTI Denpasar menggarap musik kontemporer dengan judul Mule Keto. Sebagai karya musik kontemporer perdana yang dimotori oleh mahasiswa, garapan ini mendapat sambutan antusias oleh para akademisi dibuktikan dengan semaraknya wacana yang menyertai kehadirannya. Selanjutnya ketika karya ini digelar dalam perhelatan Pesta Kesenian Bali 1987, juga mendapat respon yang beragam dari penonton. Setahun kemudian, yaitu tahun 1988 penulis menggarap karya musik kontemporer yang berjudul Belabar Agung dalam rangka Festival Seni Mahasiswa di Surakarta. Dua karya yang disebutkan terakhir ini menggunakan gamelan Gong Gede sebagai media ungkap, kehadirannya sempat mendapat kritikan dari beberapa pakar karawitan Bali karena dianggap memperkosa dan merusak kaidah-kaidah konvensional yang telah menjadi identitas gamelan Gong Gede.

Dua tahun kemudian, satu garapan musik kontemporer dengan media ungkap body dan vokal digarap kolaboratif oleh dua seniman, yaitu Wayan Dibia dan Keith Terry. Sesuai dengan medianya karya ini disebut "Body Tjak", sebuah seni pertunjukan multikultural hasil kerja sama atau kolaborasi yang memadukan unsur-unsur seni dan budaya Barat (Amerika) dan Timur (Bali-Indonesia). Menurut Wayan Dibia (2000:10) Karya Body Tjak digarap dengan penggabungan unsur-unsur seni Kecak Bali dengan Body Music sebuah musik baru yang menggunakan tubuh manusia sebagai sumber bunyi. Garapan bernuansa seni budaya global ini lahir dengan dua produk- 
sinya, yaitu Body Tjak 1990 (BT90) dan Body Tjak 1999 (BT99). Kedua karya ini memang murni lahir dari keinginan seniman untuk mengekspresikan jiwanya yang telah tergugah oleh dinamisme seni Kecak dan Body Music. Dengan berbekal pengalaman estetis masing-masing kemudian diilhami oleh obsesi aktualitas kekinian, kedua seniman sepakat melakukan eksperimen dalam bentuk workshop-workshop sehingga melahirkan musik kontemporer Body Tjak.

Kehidupan dan perkembangan musik kontemporer yang diawali event-event gelar seni baik di dalam maupun di luar negeri akhirnya masuk ke ranah akademik. Mahasiswa Jurusan Karawitan STSI/ISI Denpasar telah menaruh simpatik pada konsep-konsep kontemporer, ditandai dengan banyaknya karya-karya mereka dicipta dengan konsep garap baru ini. Pada Ujian Seniman tahun 1993, Wayan Gede Yudana dengan "berani" menyebut karyanya berjudul Laya sebagai garapan musik kontemporer, sementara peserta ujian lainnya masih menggunakan konsep kreasi baru. Pada tahun-tahun berikutnya semakin banyak mahasiswa Jurusan Karawitan menggarap musik kontemporer sebagai materi ujian akhirnya. Bahkan mulai dekade tahun 2000-an garapan mahasiswa STSI/ISI didominasi oleh karya-karya kontemporer, hal ini menunjukkan secara kuantitas penciptaan musik kontemporer telah banyak dilakukan, model, jenis, dan media ungkapnya pun sangat beragam. Penggunaan instrumen tidak hanya terpaku pada alat-alat musik tradisional Bali yang sudah ada, tetapi juga menggunakan instrumen musik daerah lain dengan mengkolaborasi, menciptakan alat musik baru, termasuk mengeksplorasi dari benda-benda apa saja yang dianggap bisa mengeluarkan suara yang mendukung ide garapannya.
Salah satu contoh adalah musik kontemporer berjudul Gerausch karya Sang Nyoman Putra Arsa Wijaya, adalah musik yang digarap untuk mendapatkan gelar Sarjana S1 Seni Karawitan tahun 2005. Karya ini diilhami oleh keinginan sang komposer untuk menata suara-suara yang umumnya dianggap "jelek", noise, tidak enak, menjadi sebuah karya musik. Kontan saja hal ini menimbulkan polemik di kalangan akademik kampus. Berkembang wacana disertai pertanyaan "apakah karya ini tergolong musik atau bukan?" Namun, jika kita berangkat dari paradigma bahwa musik adalah suara yang terorganisir yang aktualitasnya selalu berubah, maka masalah suara sumbang dan tidak enak tergantung dari mana kita menilainya. Titik tolak menilai sebuah karya musik tergantung konsep yang digunakan. Karya-karya tradisi mesti dinilai dengan kacamata tradisi, demikian halnya musik kontemporer yang telah memiliki format penilaian yang berbeda harus ditempatkan pada formulasi yang berbeda dengan musik tradisi. Jika musik tradisi menganggap polemik adalah ciri petaka, musik kontemporer mungkin berbeda, menganggap polemik, kontroversial adalah keberhasilannya.

\section{Ideologi dalam Penciptaan Musik Bali}

Definisi kata ideologi secara tepat dan bulat masih terus menerus dicari dan memerlukan studi-studi yang lebih mendalam, hal ini disebabkan karena dalam konteks intelektual kekinian, istilah "ideologi" itu sendiri menjadi sangat ideologis. Geertz (1992:3) menyebutkan bahwa pada awalnya ideologi hanya berarti sekumpulan gagasan dan saran politis, sifatnya agak intelektualistis dan tidak praksis. Namun sekarang ini pengertian ideologi berkembang, yaitu penegasan- 
penegasan, teori-teori, dan tujuan-tujuan terpadu yang menetapkan sebuah program politico-sosial, sering kali dengan sebuah implikasi propaganda yang dibuat-buat. Semua kelompok sosial memiliki ideologi, oleh sebab itu ia tidak harus dipertentangkan dengan kebenaran, melainkan digunakan sebagai alat untuk memperjuangkan kebenaran dengan pemaknaannya masing-masing. Dalam hal demikian ideologi di sini tidak bisa dilihat hanya sebagai alat dominasi, akan tetapi harus dipahami sebagai wacana-wacana dengan konskuensi-konskuensi tertentu terhadap relasi-relasi kekuasaan di setiap level hubungan sosial (termasuk juga praktik pembenaran dan penguatan kelompokkelompok yang berkuasa.

Dalam tulisan ini ideologi diartikan sebagai suatu gagasan-gagasan yang berhasil diorganisir dan tersistem lalu diberi pengertian dan pemaknaan oleh sekelompok masyarakat tertentu. Misalnya, ketika kita berbicara tentang ideologi seniman, maka sebenarnya yang dimaksud adalah gagasan-gagasan mendasar yang memberi informasi tentang visi dan praktik kelompok seniman tertentu. Dalam bidang seni lukis, munculnya gaya atau style terhadap jenis-jenis karya tertentu selalu diawali oleh adanya ideologi yang kemudian berkembang, mendapat simpati dan dukungan, akhirnya menjadi sebuah gaya. Sama halnya seperti dalam bidang politik, ideologi seniman juga sering disosialisasikan lewat propaganda menurut bahasa seni yang mereka gunakan.

Dengan pengertian di atas, maka pergulatan ideologi yang dimaksud dalam tulisan ini adalah adanya ideologi-ideologi atau kelompok-kelompok gagasan tersistem yang belum saling memahami satu sama lain. Kaitannya dengan pergulatan ideologi yang terjadi dalam musik Bali, adalah terjadinya paham-paham yang berseberangan dalam memaknai kelahiran sebuah karya musik. Implikasi dari pergulatan ideologi ini adalah tidak adanya saling mendukung sehingga memunculkan polemik yang berkepanjangan. Dalam situasi ini akan muncul "hukum rimba", yang lebih kuat dengan pendukung lebih banyak akan menguasai, sementara yang lemah akan mengalami keterpinggiran. Jika para penganut ideologi yang berbeda dapat saling memahami maka akan terjadi dialektika yang justru akan memperkaya aktualitas masing-masing.

Perkembangan dan perubahan situasi zaman telah mempengaruhi ideologi seniman musik Bali dari masa ke masa. Hingga dekade 1970-an kreativitas seniman musik Bali didominasi oleh ideologi yang bersifat konservatif, yaitu mencipta atau berkarya untuk dipersembahkan, baik kepada Tuhan maupun kepentingan sosial kemasyarakatan. Oleh karena itu, karyakarya yang diciptakan memenuhi kriteria umum, memberi rasa senang, serta sesuai dengan norma dan nilai yang berlaku. Memasuki dekade 1980-an ideologi seniman musik Bali berkembang lebih progresif. Karya-karya baru bermunculan juga di dorong oleh semangat berprestasi dan persaingan dalam rangka aktualisasi diri. Berbagai bentuk penyajian musik sengaja dikemas dalam format kompetisi untuk menunjukkan aktualitas diri baik pencipta maupun penyajinya. Bentuk-bentuk karya pada masa ini lebih bersifat inovatif, spektakuler, substansial, dan hybrid. Mulai dekade 1990-an ideologi seniman musik Bali juga berkembang ke arah fragmatisme, yaitu berorientasi pada masa kini, mengikuti selera pasar sehingga melahirkan karya-karya yang berbentuk seni pesanan. Ideologi yang melandasi proses mencipta bukan hanya untuk persembahan, kela- 
ngenan, dan aktualisasi diri, melainkan juga untuk mendapatkan finansial.

Apabila dicermati dunia penciptaan musik Bali dalam kurun waktu tiga puluh tahun belakangan ini, setidaknya ada tiga ideologi yang melandasi, yaitu pengabdian, aktualisasi diri, dan profesi komersial (Sugiartha, 2012:146). Ideologi pengabdian banyak melandasi penciptaan musik-musik tradisionil, sementara ideologi aktualisasi diri dan profesi komersial banyak melandasi penciptaan musik-musik kontemporer. Dalam perkembangannya para penganut ketiga ideologi ini melakukan pergulatan wacana khususnya antara mereka yang masih kuat menganut paham tradisi dengan mereka yang ingin membongkar paham-paham lama untuk mengikuti trend perkembangan zaman.

\section{Ideologi Penciptaan Musik Tradisional}

Ideologi penciptaan musik tradisional Bali dapat diamati sedikitnya melalui tiga konsep, yaitu pelestarian tradisi, keseimbangan, dan kelangenan. Tiga konsep ini yang melandasi seniman musik Bali dalam berkarya dari waktu ke waktu sehingga pada akhirnya menjadi ideologi. Ideologi yang dipraktikkan secara terus menerus dalam kurun waktu yang sangat lama akhirnya menjadi sesuatu yang hidup, diyakini, dan dibanggakan, sehingga untuk melakukan perubahan terhadap prinsipprinsip yang terkandung dalam ideologi tersebut sangat susah. Demikian halnya ketika muncul ideologi baru sebagai dampak dari perubahan paradigma berkesenian terjadi pergulatan wacana di antara para pencipta maupun penyaji seni. Masyarakat penikmat pun akhirnya disuguhi dengan "pertunjukan" kontestasi ideologi yang tidak jarang memunculkan polemik.

Konsep pelestarian tradisi adalah sebuah narasi besar yang bertujuan sangat mulia, yaitu menjadikan tradisi tetap aktual karena tradisi dipandang banyak mengandung nilai yang berguna bagi kesejahteraan umat manusia. Akan tetapi jika konsep pelestarian tradisi tidak dimaknai dengan baik maka dapat menimbulkan persepsi yang cenderung bersifat kaku. Sebagai contoh jika tradisi dimaknai sebagai "mempertahankan", atau sesuatu yang tidak bisa dirubah kendatipun tradisi tersebut sudah tidak sesuai dengan situasi zaman. Pandangan bahwa tradisi harus dipertahankan justru akan berdampak menyesatkan tradisi itu sendiri, sebab manusia sebagai pelaku tradisi adalah mahluk hidup, mahluk sosial yang selalu berinteraksi dan berubah. Tradisi juga hendaknya mengikuti perubahan, sebagai sesuatu yang hidup dalam kehidupan masyarakatnya, dengan demikian ia akan menjadi aktual secara terus menerus.

Tradisi adalah hasil cipta dan karya manusia berbentuk obyek material, kepercayaan, sistem, khayalan, atau lembagalembaga yang diwariskan dari satu generasi ke generasi berikutnya. Ringkas kata, tradisi adalah segala sesuatu yang diwarisi dari masa lalu. Akan tetapi sesuatu yang diwariskan tidak berarti harus diterima, dihargai, diasimilasi, atau disimpan sampai mati. Tradisi itu berkembang dan berubah, dengan demikian ia tidak lagi dipertentangkan dengan perubahan dan penemuan. Tidak ada masyarakat yang hidup hanya dari produk-produk yang diwarisi dari generasi sebelumnya. Sebaliknya tak dapat pula dibayangkan sebuah generasi yang mampu menciptakan segala keperluan hidupnya sama sekali baru, tanpa belajar dari pendahulunya.

Tersebut di atas adalah cara pandang seniman musik Bali dalam berkreativitas. Tradisi dipandang sebagai spirit budaya yang tak akan pernah terbunuh, karena ia 
selalu tumbuh dalam suatu proses yang terus menerus dalam bentuk konvensi, transformasi, konflik, inovasi, bahkan anarki (Harjana, 2004:64). Kesinambungan proses inilah yang membuat musik tradisional Bali selalu aktual dan terus menerus menemukan nilai-nilai barunya. Bagi seniman musik Bali, upaya melestarikan musik tradisional adalah bagian dari pengabdian atau ngayah yang dipahami sebagai bekerja untuk kepentingan yang lebih luas, yaitu Sang Pencipta, masyarakat, dan pemerintah. Selain itu pengabdian juga ditujukan untuk eksistensi jagat seni, agar kesenian tetap lestari dan aktual. Mencipta musik untuk kepentingan ritual di Pura, menghibur masyarakat, atau membantu pemerintah dalam menjalankan programprogram kemanusiaan adalah salah satu bentuk pengabdian sekaligus melestarikan musik tradisi. Upaya penggalian seni-seni langka melalui kegiatan revitalisasi, rekonstruksi, dan reaktualisasi juga merupakan bentuk pengabdian terhadap jagat seni karena dengan kerja kreatif seniman dapat menghidupkan kembali seni-seni langka.

Selain pelestarian tradisi, ideologi penciptaan musik tradisional Bali juga dapat diamati dari konsep keseimbangan yang dianut oleh seniman dalam berkarya. Dalam lontar Prakempa disebutkan bahwa filsafat atau logika yang melandasi perbuatan manusia Bali terwujud dalam keseimbangan berdimensi tunggal, berdimensi dualitas, berdimensi tiga, berdimensi empat, berdimensi lima, berdimensi enam, berdimensi tujuh, berdimensi delapan, berdimensi sembilan, dan berdimensi sepuluh (Bandem, 1986:11-12). Seniman musik Bali yang kreativitasnya dilandasi oleh agama Hindu menganut konsep keseimbangan dalam beberapa dimensi.

Pertama, keseimbangan berdimensi tunggal tercermin dari adanya instrumen gong yang berfungsi sebagai finalis memberi makna ada kekuatan tunggal dalam musik Bali yang menandai setiap akhir sebuah frase atau kalimat lagu. Tanpa adanya kekuatan tunggal yang memberikan tekanan awal dan akhir, rasa musikal musik Bali dianggap kurang sempurna. Kedua, keseimbangan berdimensi dualitas mengandung makna ada dua hal yang berlawanan namun harus dipadukan, dalam ilmu estetika instrumental hal demikian disebut asimetric balance. Dalam musik tradisional Bali dua hal yang berlawanan terdapat pada konsep baik fisik, musikalitas, dan fungsi seperti lanangwadon (laki-perempuan), polos-sangsih (onbeat-ofbeat), dan pengumbang-pengisep (nada lebih rendah-nada lebih tinggi, dalam nada yang sama). Sebagai contoh instrumen gong dan kendang haruslah berpasangan secara diametral (lanang-wadon), artinya unsur yang satu memerlukan kehadiran yang lain guna saling melengkapi, jika tidak akan terjadi kepincangan. Demikian halnya dengan instrumen gangsa terdiri dari yang bernada pengumbang (lebih rendah) dan pengisep (lebih tinggi) bertujuan mendapatkan suara yang bergetar dan bergema (pelayangan) ketika dipukul bersamaan. Ketiga, keseimbangan berdimensi tiga tercermin dari struktur musik tradisional Bali yang terdiri dari tiga bagian, yaitu pengawit, pengawak, dan pengecet. Struktur ini berpedoman pada konsep tri angga, yaitu tiga bagian utama tubuh manusia seperti kepala, badan, dan kaki. Pengawit ibarat kepala dimana wajah berada pada lokasi ini dan dalam musik Bali bagian awal ini ditandai dengan pengenalan, introduksi untuk mengetahui jati diri sebuah lagu. Pengawak ibarat badan (main body) yaitu bagian utama tubuh yang di dalamnya terdapat organ-organ vital. Dalam struktur karawitan Bali pada 
pengawak inilah bagian yang paling pokok, biasanya kalimat lagu lebih panjang, dan lengkap. Pengecet ibarat kaki manusia yang dapat bergerak lincah dan dinamis, dalam musik Bali bagian pengecet selalu dikemas lebih lincah, penuh dinamika sebelum mengakhiri sebuah lagu. Dengan menganut konsep tri angga, sebuah lagu akan dirasa kurang lengkap jika dalam strukturnya tidak memasukkan pengawit, pengawak, dan pengecet. Keempat, keseimbangan berdimensi empat tercermin dalam struktur nada beberapa gamelan Bali seperti angklung, bebonangan, dan jegog yang semuanya berjumlah empat. Selain itu konsep berdimensi empat juga tercermin dalam teknik permainan yang disebut ngempat (memukul nada no 1 dan no 4 sekaligus) sebagai sebuah konsep harmonisasi gamelan Bali. Kelima, keseimbangan yang berdimensi lima dan tujuh dapat diamati dari struktur nada gamelan Bali yang berjumlah lima (ding, dong, deng, dung, dang) sebagaimana terdapat dalam gamelan Gender Wayang, Gong Gede, Kebyar, Palegongan, Babarongan, dan Joged Pingitan dan struktur nada gamelan Bali yang berjumlah tujuh (ding, dong, deng, deung, dung, dang, daing) seperti terdapat dalam gamelan Gambang, Selonding, Gong Luang, Semara Pagulingan Saih Pitu, Genta Pinara Pitu, dan Semarandana. Dalam sistem musikal musik Bali sesungguhnya nada pokok terdiri dari lima sebagaimana yang terdapat pada gamelan pelog lima nada. Penambahan dua nada (deung dan daing) sehingga menjadi tujuh adalah nadanada yang disebut pemero. Namun hal ini bukan berarti dua pemero ini hanya sebagai pelengkap, melainkan dengan adanya dua pemero inilah nada gamelan Bali dapat diperluas dengan sistem nada fungsional (patet) termasuk munculnya nada-nada selendro dalam berbagai karakter.
Konsep selanjutnya yang juga merupakan ciri ideologi penciptaan musik tradisional adalah kelangenan atau keindahan Konsep kelangenan mencakup pengetahuan bagaimana sebuah musik bisa memberikan kenikmatan, baik secara ilmiawi maupun falsafi kepada penontonnya. Musik sebagai sebuah karya seni memiliki sifat transfer of feeling atau pemindahan rasa. Hal ini berarti jika seorang komposer ingin mengekspresikan rasa senang, sedih, lucu lewat musik, maka keberhasilannya terletak pada jika penikmat juga dapat merasakan senang, sedih, atau lucu. Jika tidak, misalnya komposer ingin mengekspresikan rasa senang tetapi penikmat merasakan sesuatu yang sedih maka sang komposer dianggap belum berhasil.

Mengenai konsep kelangenan dalam musik Bali banyak dimuat dalam lontar Prakempa dan Aji Gurnita. Menurut falsafah Prakempa, bahwa bunyi (suara) diciptakan oleh Bhagawan Wiswakarma dan ciptaan beliau mengambil ide dari bunyi delapan penjuru dunia yang sumbernya berada di dasar bumi. Suara-suara itu dibentuk menjadi sepuluh nada yaitu lima nada yang disebut laras pelog dan lima nada yang disebut laras selendro. Nada-nada tersebut mempunyai kaitan dengan pabca tirta manifestasi Bhatara Semara (pelog) dan panca geni sebagai manifestasi Dewa Ratih (selendro). Mitologi ini akhirnya dijadikan pegangan oleh para komposer Bali dalam berkarya. Jika komposer ingin menciptakan lagu yang berkarakter laki-laki maka orientasinya adalah menggunakan nadanada dalam laras pelog, begitu sebaliknya untuk menciptakan lagu-lagu berkarakter perempuan maka digunakan laras selendro.

Selain falsafah tentang laras yang sangat diyakini masing-masing memiliki karakter, juga terdapat konsep karakter atau 
watak nada-nada gamelan Bali yang memiliki kekuatan untuk mempengaruhi suasana hati. Sebagai contoh, nada deng memiliki karakter magis, nada ding memiliki karakter romantis, nada dung memiliki karakter manis dan lembut, nada dong memiliki karakter lucu, nada dang memiliki karakter lincah dan dinamis. Dengan berpedoman pada konsep ini, jika komposer ingin membuat lagu-lagu yang bernuansa lembut dan manis maka permainan melodi akan lebih didominasi dan diakhiri dengan dung. Demikian halnya jika ingin membuat lagu yang berkarakter magis, seram, maka permainan melodi didominasi dan diakhiri dengan nada deng. Namun harus diakui pula bahwa watak nada tidaklah berlaku mutlak, masih ada unsur-unsur musikal lainnya yang mendukung pencapaian karakter sebuah lagu, yaitu tempo, dinamika, dan warna suara.

Tersebut di atas telah dipaparkan ideologi dengan berbagai konsep yang digunakan dalam penciptaan musik tradisional Bali. Bagi seorang komposer yang tradisionalis konsep-konsep di atas dipegang teguh dengan sebuah keyakinan bahwa itulah ciri khas musik tradisional Bali. Dengan konsep pelestarian tradisi mereka memandang pembaharuan dan kreativitas sangat diperlukan, dengan konsep keseimbangan mereka meyakini bahwa musik Bali mengandung falsafah sebagaimana kehidupan manusia di dunia ini. Demikian halnya dengan konsep kelangenan sebagai falsafah tentang keindahan tetap mewarnai cara pandang dan perlakuan mereka terhadap unsurunsur musikal.

\section{Ideologi Penciptaan Musik Kontemporer Bali}

Sebagaimana telah dipaparkan di atas bahwa penciptaan musik tradisional lebih berorientasi pada pelestarian tradisi, penciptaan musik kontemporer Bali lebih berorientasi pada semangat dan tekad untuk mengembangkan tradisi. Para penggiat musik kontemporer sadar bahwa musik tradisional Bali harus berkembang, baik dari segi konsep atau ide, bentuk, maupun tata penyajiannya agar mengkuti perkembangan zaman. Tuntutan zaman dan selera budaya masa kini tampaknya tidak mampu terwadahi oleh konsepkonsep dan teori-teori klasik yang bersifat "kaku", terutama yang selalu mematok pemahaman budaya "harus ini" dan "harus itu". Sudah saatnya para komposer Bali menggunakan konsep-konsep penciptaan yang sesuai dengan pemikiran postmodern kendatipun masih menggunakan bahanbahan atau objek material musik tradisi. Konsep pemikiran postmodern berpendapat bahwa kebenaran tidak pernah terbayangkan, karena ia tidak selalu hadir dari unsur-unsur budaya yang besar. Kebenaran perlu dicari dengan memaknai budaya secara kreatif dan adaptif, jika perlu dengan mendekonstruksi konsep-konsep dan pemikiran sebelumnya guna menemukan kebenaran dalam arti sesungguhnya.

Namun sangat disadari bahwa prinsip pemikiran postmodernis bukan berarti menolak rasionalitas yang telah dibangun oleh kaum interpretif sebelumnya, melainkan lebih pada keinginan untuk mencari makna baru melalui kebenaran aktif kreatif. Logika yang digunakan menemukan kebaruan tanpa standar yang pasti. Bagi kaum postmodernis, kebenaran yang selalu mengandalkan grand theory dan grand naratif sudah tidak relevan lagi, mereka lebih menghargai perbedaan, pertentangan, paradoks, dan misteri di balik fenomena budaya. Pemahaman seperti tersebut di ataslah yang menjadi sandaran bagi para penggiat musik kontemporer Bali 
berkreativitas. Pemikiran ini juga yang pada akhirnya melahirkan bentuk-bentuk musik baru yang berparadigma baru dengan tampilan yang cukup berbeda dengan musik-musik Bali sebelumnya.

Jika dicermati dari latar belakang munculnya musik kontemporer Bali, ia lahir disebabkan oleh kegelisahan senimanseniman muda terhadap kemapanan konsep, aturan, dan struktur dalam musik tradisi yang dianggap membelenggu kreativitas. Seniman menginginkan kebebasan dalam berekspresi, bereksplorasi, tidak hanya dari tataran musikal atau mengolah melodi dan ritme, melainkan sampai pada hal-hal detail seperti menemukan instrumen-instrumen baru, menemukan tata penyajian baru yang lebih kreatif dan adaptif. Munculnya musik kontemporer Bali secara perlahan mendapat dukungan dari para seniman muda, dan pada akhirnya berkembang menjadi sebuah genre baru yang ikut meramaikan jagat musik Bali.

Sebagaimana halnya dalam penciptaan musik tradisional, kelahiran musik kontemporer Bali juga diandasi oleh beberapa konsep pemikiran dan cara pandang. Meminjam prinsip-prinsip dalam etnomusikologi sebagaimana yang dipaparkan oleh Santosa (2009:2-3), bahwa dalam memandang sebuah musik harus dipahami tiga prinsip, yaitu relativitas, pluralitas, dan identitas. Ketiga prinsip ini sangat sesuai dengan cara pandang penggiat musik kontemporer Bali dan prinsip ini dapat dijadikan konsepsi bahkan ideologi dalam berkreativitas. Pertama relativitas, para penggiat musik kontemporer Bali berpandangan bahwa kehidupan musik bervariasi atau beragam baik bentuk, penyajian, maupun nilai-nilai budaya yang dikandung. Oleh sebab itu mereka menghindari penilaian sebuah karya musik dengan indikator-indikator seperti jelek, bagus, atau peringkat, karena semuanya memiliki konsep, bentuk, dan cara penyajian yang khas. Musik tradisi yang telah memiliki konsep, bentuk, dan penyajian yang mapan hendaknya tidak dipandang sebagai sesuatu yang dikotomis dengan musik baru termasuk yang "mendobrak" aturan serta konsep-konsep musik tradisi. Musik baru hendaknya dipandang sebagai perkembangan dari musik tradisi guna menawarkan nuansa lain yang tentu dapat memperkaya cakrawala dunia musik. Sebagai contoh musik kontemporer berjudul Geraush karya Sang Nyoman Arsawijaya kualitas estetiknya adalah relatif tergantung sudut pandang kita. Jika karya ini dinikmati melalui kacamata musik tradisi maka kita tidak akan mendapatkan apa yang kita inginkan, melainkan sesuatu yang bertentangan karena dalam karya ini kita disuguhkan sesuatu yang justru tidak enak, tidak nyaman, bahkan cenderung membuat penikmat jengkel. Dalam musik kontemporer Gerausch keindahan yang ingin ditawarkan oleh sang komposer bukanlah untuk membuat orang senang dan nyaman, melainkan aktivitas intelektual yang tersimpan dalam karya tersebut yang bagi kebanyakan orang tidak teramati.

Kedua pluralitas, para seniman kreatif memandang keragaman baik fisik, musikalitas, maupun penyajian adalah modal yang handal untuk melahirkan komposisi musik yang kreatif. Hal ini sesuai dengan pandangan Beardsley (Djelantik, 1992:66) yang menyatakan salah satu hal yang dapat menambah kualitas estetik sebuah karya seni adalah kompleksitas atau keragaman yang dipandang memiliki fungsi yang sama dalam mendukung kualitas. Dalam hal fisik atau instrumentasi misalnya, seorang komposer musik kontemporer 
mengeksplorasi tidak hanya alat-alat musik tradisional etniknya sendiri melainkan juga lintas etnik, bahkan menciptakan alat-alat musik baru untuk mendukung gagasannya. Seringkali para komposer juga menggunakan alat-alat keseharian, seperti sapu lidi, box triplek, tiang telefon, gergaji, atau apa saja yang bisa mengeluarkan bunyi, diangkat menjadi alat musik. Dari segi musikal, komposer musik kontemporer Bali juga menggunakan tangga nada dari musik-musik lainnya seperti Mandarin, diatonis, India, atau menciptakan tangga nada baru. Cara pengolahannya pun beragam, untuk menghindari kesan monoton mereka menggunakan berbagai tangga nada secara bergantian. Ditambah dengan permainan ritme dan dinamika yang juga lintas etnik menjadikan musik kontemporer Bali bernuansa sangat plural. Dalam hal penyajian, musik kontemporer Bali sangat fleksibel, panggung pertunjukannya disesuaikan dengan tema, sehingga tidak jarang dilakukan di halaman rumah, persawahan, atau pinggir pantai. Pengaturan instrumen juga menyesuaikan dengan tempat pertunjukan, terkadang berpindah-pindah sesuai tema yang dimainkan.

Ketiga identitas, yang dimaksudkan dalam hal ini adalah sebuah karya musik tentu menginginkan adanya identitas baik sifatnya pribadi sang komposer maupun identitas sebuah etnik tertentu. Pencarian identitas selalu menjadi pertimbangan yang cukup penting bagi sang komposer ketika menciptakan musik, karena dengan identitas mereka dapat menunjukkan jati dirinya lebih aktual sebagai seorang komposer. Dari sekian banyak komposer musik kontemporer Bali, seperti Nyoman Windha, Gede Yudana, dan Sang Nyoman Arsa Wijaya ketiganya sangat kental dengan identitas pribadinya masingmasing. Nyoman Windha yang terlahir dari
Banjar Kutri, Singapadu, Gianyar, sebuah daerah dengan lingkungan seni tradisi yang kuat, karya-karyanya memiliki ciri khas pada kekuatan permainan melodi. Windha sangat piawai mengolah melodi, bermain nada-nada fungsional, dan menemukan model-model melodi baru. Kegemaran Windha mendengarkan lagu-lagu etnis lain seperti Jawa, Sunda, Mandarin, dan Musik Barat membuat ia memiliki kepekaan dan dengan mudah membuat melodi-melodi bernuansa baru. Jika Windha beridentitas melodi maka Yudana suka bermain ritme. Kesukaan Yudana berinteraksi dengan komposer-komposer musik Barat menjadikan ia selalu mencoba memasukkan pola-pola permainan seperti canon, call and respon, counterpoint ke dalam karya-karyanya. Berbeda dengan Windha dan Yudana, Sang Nyoman Arsawijaya terkenal dengan "si petualang sejati". Arsawijaya suka dengan sesuatu yang aneh, tidak biasa, eksentrik, kendatipun banyak karya-karyanya tidak dapat dicerna oleh penikmat. Namun demikian ia pun tidak peduli, pencarian demi pencarian itulah yang memberikan ia kenikmatan dalam berkarya dan hal itulah identitasnya.

Selain identitas pribadi, identitas budaya lokal juga sangat banyak mengilhami para komposer dalam berkarya. Pada umumnya komposer musik kontemporer Bali suka mengangkat kearifan budaya lokalnya sebagai materi untuk dikembangkan menjadi musik baru. Identitas budaya lokal yang dimaksud di sini bukan hanya dalam bentuk seni tradisional yang telah ada di daerah asal sang komposer, melainkan juga suasana lingkungan yang berpotensi mempengaruhi ekspresi estetik warganya. Sebagaimana telah disebutkan di atas, Windha yang berasal dari kampung yang kehidupan seninya sangat subur, seperti terkenalnya arja dan calonarang 
Singapadu menjadikan ia suka menggarap musik dengan mengedepankan melodi dan permainan vokal. Sementara Yudana dan Sang Nyoman Arsawijaya yang tinggal di Banjar Kaliungu Kaja, Kota Denpasar, persentuhannya dengan situasi kota serta banyaknya komposer-komposer asing yang berinteraksi di Kota Denpasar membuat identitas karya-karya kedua komposer ini cenderung bercirikan kolaborasi dengan musik asing. Identitas lokal yang masih ditemui pada musik-musik kontemporer inilah menjadikan karya tersebut menarik dan bisa dicerna oleh penonton lokal. Dari segi musikal hal seperti ini merupakan aktivitas kreatif, namun tidak jarang juga penggunaan unsur-unsur lokalitas menuai kecaman karena dianggap merusak pakem. Dalam hal inilah dituntut kecermatan komposer dalam meramu, memasukkan identitas lokal tidak dengan cara memaksakan akan tetapi justru menjadikannya lebih segar dan lebih mudah diapresiasi.

\section{SIMPULAN}

Musik kontemporer yang lahir dari alam pemikiran postmodern memunculkan fenomena kultural, yaitu pergulatan ideologi. Pergulatan ideologi terjadi antara mereka yang memahami musik dengan kacamata tradisi dengan mereka yang memahami musik dengan kacamata kekinian sebagai produk pemikiran kontemporer. Dalam musik kontemporer pun juga terjadi pergulatan ideologi antara mereka yang lebih menyukai perubahan bertahap dengan mereka yang menyukai perubahan radikal. Bagi komposer yang berideologi perubahan bertahap memandang tidak perlu membongkar struktur, melainkan lebih pada variasi, bertujuan agar penikmat dapat segera mencerna karya-karya tersebut. Namun bagi komposer berideologi perubahan radikal justru sebaliknya, pembongka- ran struktur itu perlu agar menghasilkan sesuatu yang baru. Jika struktur dipertahankan hanya akan melahirkan musik yang monoton (begitu-begitu saja) dan tentu hal demikian dianggap kurang kreatif. Situasi ini merupakan tantangan bagi perkembangan musik kontemporer Bali. Memang harus diakui, memperkenalkan sebuah ideologi baru di tengah dominasi tradisi memerlukan perjuangan, kesabaran, dan ketabahan. Itulah yang kini sedang diperjuangkan oleh para penggiat musik kontemporer Bali, tiada henti memacu prestasi dengan melahirkan karya-karya mutakhir.

Apakah yang mendorong perjuangan para penggiat musik kontemporer Bali, tiada lain adalah untuk bisa mensejajarkan karya-karya musik kontemporer dengan kemapanan musik tradisional Bali yang telah mendunia. Namun apabila dicermati dari sisi pribadi para komposernya, perjuangan mereka selain didorong oleh semangat mengekspresikan jiwanya, juga mengandung motif berprestasi, aktualisasi diri untuk menunjukkan bahwa mereka telah mampu berkarya.

Sementara para penggiat musik kontemporer yang berideologi perubahan bertahap berpandangan lain, yaitu mempertahankan suatu keseimbangan dinamik lewat variable-variabel yang non-maksimasi dan kelenturan dalam sistemnya. Dengan demikian, konsep pembaharuan yang ditawarkan adalah bertahap namun lentur dalam variasinya.

\section{Daftar Pustaka}

A.A.M. Djelantik

1992 Pengantar Dasar Ilmu Estetika Jilid II, Falsafah Keindahan dan Kesenian. Denpasar: SekolahTinggi Seni Indonesia.

Cavarrubias Miguel

1972 Island of Bali. Kuala Lumpur: Oxford University Press. 
Edi Sedyawati

1981 Pertumbuhan Seni Pertunjukan. Jakarta: Sinar Harapan.

Geertz Clifford

1992 Politik Kebudayaan. Yogyakarta: Kanisius.

Holt Claire

1967 Art In Indonesia Continuities and Changes. Ithaca New York: Cornell University Press.

I Gede Arya Sugiartha

2012 Kreativitas Musik Bali Garapan Baru di Kota Denpasar (Disertasi). Denpasar: Program Pascasarjana Universitas Udayana Denpasar.

I Made Bandem

1986 Prakempa, Sebuah Lontar Gamelan Bali. Denpasar: Akademi Seni Tari Indonesia Denpasar.

I Wayan Dibia

2000 "Body Tjak Karya Kolaborasi Seni Budaya Global" dalam Jurnal Seni Budaya Mudra No. 8 Tahun VIII. Denpasar: UPT Penerbitan STSI Denpasar.

Jiwa Atmaja

1993 "Seni Kontemporer". dalam Brosur Festival Seni Masa Kini, Denpasar: Yayasan Walter Spies,
Rustopo

1991 Gamelan Kontemporer di Surakarta, Pembentukan dan Perkembangannya (1970-1990) (Laporan Penelitian). Surakarta: Sekolah Tinggi Seni Indonesia Surakarta.

Santosa

2009 "Etnomusikologi dalam Pembentukan Peradaban Manusia", dalam Pidato Pengukuhan Guru Besar Pada Jurusan Etnomusikologi ISI Surakarta.

Suka Harjana

2003 Corat-Coret Musik Kontemporer Dulu dan Kini. Jakarta: The Ford Foundation dan Masyarakat Seni Pertunjukan Indonesia.

2004 Musik Antara Kritik dan Apresiasi. Jakarta: Buku Kompas.

Umar Kayam

1981 Seni, Tradisi, Masyarakat. Jakarta: Sinar Harapan.

Zulkarnaen Mistortoify

2009 "Yang Muda Dia Bukan Musik Biasa", dalam Majalah Gong. Yogyakarta: Yayasan Tikar Media Budaya Nusantara. 